\title{
Miranda
}

Revue pluridisciplinaire du monde anglophone /

Multidisciplinary peer-reviewed journal on the English-

speaking world

19 | 2019

Rethinking Laughter in Contemporary Anglophone Theatre

\section{Interview with Maria Giese, April 16, 2019}

\section{Cristelle Maury and David Roche}

\section{Q OpenEdition}

\section{Journals}

Electronic version

URL: http://journals.openedition.org/miranda/22570

DOI: 10.4000/miranda.22570

ISSN: 2108-6559

\section{Publisher}

Université Toulouse - Jean Jaurès

Printed version

Date of publication: 7 October 2019

\section{Electronic reference}

Cristelle Maury and David Roche, "Interview with Maria Giese, April 16, 2019", Miranda [Online], 19

2019, Online since 15 October 2019, connection on 16 February 2021. URL: http://

journals.openedition.org/miranda/22570 ; DOI: https://doi.org/10.4000/miranda.22570

This text was automatically generated on 16 February 2021.

\section{$\Theta \Theta \Theta \Theta$}

Miranda is licensed under a Creative Commons Attribution-NonCommercial-NoDerivatives 4.0 International License. 


\title{
Interview with Maria Giese, April 16, 2019
}

\author{
Cristelle Maury and David Roche
}

1 We interviewed Maria Giese on Tuesday, April 16 via the video conference system RENATER at Université Toulouse Jean Jaurès and NYC. Additional questions were provided by our colleague Hélène Charlery.

2 Maria Giese is an American journalist, screenwriter and director. She holds a Master's degree from UCLA's Graduate School of Theatre, Film and Television. She wrote and directed the feature films When Saturday Comes (1996), starring Sean Bean and Pete Postlethwaite, and Hunger (2001). In 2015, after four years of activism in the Directors Guild of America, Giese became the person who instigated the biggest industry-wide Federal investigation for women directors in Hollywood history. In The New York Times, Manohla Dargis referred to her work as "a veritable crusade." She has an upcoming book, Troublemaker, which describes her work getting the ACLU and EEOC to investigate this issue-the ramifications of which are resonating globally.

CM: To begin with, could you tell us how it all started for you. You said in a Ted Talk, "The Battle for Women's Voice in Entertainment Media," that you were given \$2 million funding to direct When Saturday Comes. Can you tell us more about that?

MG: Sure. My love of cinema started at a very young age. I grew up in Puerto Rico, which is a visually magical place, and I had a very lively dream world. My mother is a landscape photographer and my father is an oceanographer-they both encouraged me to write and draw, to be a storyteller. We didn't have a TV or even a telephone in those early years, but when I first saw a film, I felt like that was very close to dreaming, and I grew fascinated with the idea of putting dreams on film.

Then when I was 9 years old, my family moved back to Cape Cod. In Provincetown there was a wonderful art house movie theater, "The Movies", which played European and international cinema rather than American films. From my early teens I was exposed to German film, French avant-garde, Italian neo-realism. I was inspired by so many filmmakers: Herzog, Antonioni, Kurosawa, De Sica, Fellini and Bunuel. And then when I was about fourteen, I saw the film Swept Away by Lina Wertmüller. I 
don't think I had really imagined myself as a film director. I wanted to make films, I wanted to be able to do what I saw these extraordinary auteur directors doing, but I don't think it really hit home that I could do it until I saw Swept Away. I never changed my course after that. That was all I wanted to do.

I think Swept Away struck me also because it centered on politics and gender. Looking back, I was very interested in sociopolitical films from early on, and the influence they could have on culture. That would grow in me more and more as time went on and eventually come to define my life wok.

There wasn't really a lot of access at that time to study film, especially when you're a kid on Cape Cod. Screenplays were not getting published frequently in the late 1970s, but I was able to get hold of three collections of Bergman, Antonioni, and Lina Wertmüller screenplays. So I read those over and over again, and then at age 16 I was accepted to Simon's Rock of Bard College, which is an early college. They didn't have a film program, but I ran the film society and became a projectionist. In this way I was able to research and watch a lot of movies. I poured through the thick rental catalogues of $16 \mathrm{~mm}$ films offered by distribution companies and really learned about the whole history of cinema, who was who and what stories they told.

\section{Studying at Wellesley College and UCLA}

Then I went to Wellesley College, one of the first women's colleges in the United States. Oddly, Wellesley didn't have a filmmaking program either. I often wonder why women's colleges didn't have an emphasis on entertainment media storytelling when it was quickly becoming the most effective method of getting women's voices into our cultural narrative, and was so incredibly influential. In any case, I continued working as a projectionist, studying film, and writing my own screenplays. After getting my BA in 1988, I finally got the opportunity to apply to film school. I was accepted into UCLA's five-year graduate film program. I literally felt like I had won the lottery, being able to do what I had dreamed of for so long.

It was 1989 and my class was about 50/50 men and women thanks to Title IX, part of the Civil Rights Act of 1964. Title IX was written into law by Richard Nixon in 1972 and provides for equal opportunity for women in education and sports. I felt so at home for five years in this program-some of the happiest days of my life. I made several shorts and won quite a few awards. My third short, "A Dry Heat" won the top award at film school, a "Spotlight Award" and was a finalist for the Student Academy Awards that helped me get an agent by 1991. I worked consistently as a teacher's assistant, and I also started writing professionally. So, as I was excelling as a student, I also was doing script-doctoring and observing on prime time episodic TV shows, like LA Law and Crime and Punishment.

\section{How When Saturday Comes came about}

While all this was going on, the screenplay, When Saturday Comes, began to evolve. It was the story of my ex-husband's life growing up in Sheffield, England, dreaming of becoming a professional football player. He had actually made it to trials on Huddersfield United, but that was as far as he'd gotten. He was always telling me 
colorful stories of his childhood growing up in a tough working-class neighborhood in Sheffield, England. These stories were like a capsule in time, and so different from my sort of elite New England upbringing. There was a lot of drinking and fighting and poverty, and school beatings and working in factories. I think I really saw his childhood stories through the lens of my love of British Kitchen Sink films, and I thought it would make a great movie.

At about this time I got hired to rewrite a screenplay based on a 1956 novel called The North Star for Nils Gaup, the indigenous Norwegian director who had directed the hit film, Pathfinder. The first draft had been written by the iconic Italian screenwriter, Sergio Donati (who had written the Spaghetti Westerns for Clint Eastwood), and his son Lorenzo, but the script was not strong and had not been able to get financed. Christophe Lambert was starring in the film and he hired me to rewrite it. I went back to the Henry Wilson Allen novel for a page one re-write and grew fascinated with the subject matter. It was about the Gold Rush in Nome, Alaska with people streaming in competing for gold strikes. There was a tremendous discrimination against immigrants coming in to compete. So-called "Americans" (who were of course all immigrants anyway) tried to get laws passed to keep them out and prevent them from competing for strikes. Christophe played a Native American who gets caught in the middle of this dramatic action film centered around a chase.

It was so much fun to work on this project and my rewrite got US\$4 million from 20th Century Fox, as well as the attachments of stars, James Caan and Catherine McCormack. The film was quickly greenlit to start shooting and I was brought out to Oslo to work with the director on the script. Right at the same time Christophe Lambert read When Saturday Comes and wanted to produce it. He put me together with producer Meir Teper, and an executive from New Regency named David Matalon who in turn introduced me to two women producers, Sharon Harel and Jane Barclay, who were making some of the best films in England at that time-their company was called Capitol Films. I met with them and even though I had never directed a feature film, they quickly saw the potential and gave us the green light.

It sounds easy, but the truth is before I met with Capitol we had been turned down by about 40 production companies in the US. Many of them had asked me: "Would you be willing to give us the script and we'll bring on a male director?" My agent had advised me, "Just say no, tell them if you want a different director, get a different script." And that (laughs) seemed to work really well in terms of people dropping the project and not wanting to do it. So you can imagine I was pretty relieved and excited when Capitol said yes to me as the director. They financed a $\$ 2$ million budget, and we went very fast-track into production.

One of the reasons we got greenlit was because we got Sean Bean attached to star. His mom lived in Sheffield not too far from where my ex-husband's family lived, and girlfriend of his brother's lived next door to Sean Bean's mom. She dropped the script off for Sean. When he saw it was about Sheffield United, he was like "Fuckin' hell, United!" (laughs). He called (producer) Jimmy Daly and said: "Y' must be pullin' me plonker! Let's do it!" He was really excited to do a screenplay about his beloved football team, Sheffield United, and he brought on Academy Award-nominee Pete Postlethwaite who he'd been starring with on the successful British TV movie, Sharpe's Rifles (1993). Then, Christophe Lambert brought on Emily Lloyd and the rest 
is history. We started crewing up with some of the best cast and crew out of England and Scotland at the time.

DR: Good! We'll talk about the movie again later on, but there are two things that you touched on that are actually questions we had for you later. So one was basically had you spent time in Great Britain before making that movie, given that your ex-husband was British? We were obviously very much intrigued by an American director making her first movie such a British movie. And then the second thing you touched on but that we also wanted to ask you later we can talk about now maybe, is you said you were very interested in documentary and films that had a socio-political intent and so forth, do you have any feelings or thoughts on documentary versus fiction? Do you see them as complementary? What are your feelings in terms of the socio-political impact they can have?

MG: (laughs) I have thoughts on everything. When you grow up somewhere you don't necessarily see the extraordinariness of it. Coming from the outside provides objectivity and discovery. I was fascinated with the ancient tribal nature of football culture in Northern England. And I was struck by how difficult it was to move between the classes. So, even though we were very much trying to make a sports success story in the spirit of Rocky, we were also exploring the culture of poverty, failure, and alcoholism. I also had a brother who died of alcoholism in a motorcycle accident in 1986 when I was 23, so I brought the heartbreak of that experience into the film. There were a lot of things that were deeply personal to me about that film.

\section{Documentary and the fiction film}

To answer the second part of the question: I think if as filmmakers we care about making a socio-political difference in the world, then the way our fiction narratives blend with documentary truth can be fluid. When we tell stories, our life experiences and understanding of the world are deeply integral to them. I was very inspired by the films of Gillo Pontecorvo, Burn for example. He claimed he made films only when he absolutely had to because the world needed to know something. He mixed a lot of fact and fiction. But there's often quite a lot of intertwining of documentary and fiction in the films I love-I'm thinking now for example of 400 Blows-Truffaut was telling his own deeply personal story of childhood, lacing fiction and fact.

Perhaps that's why I never really responded that well to Hollywood films-as primarily made-up stories, they often had this singular objective of entertaining people. While from my experience, non-American films- those of Satyajit Ray, or Kurosawa, just as examples-functioned on a deeper, richer basis that seemed more meaningful to me. They opened up new universes of culture and politics and human experience that made them transformative rather than simply entertaining.

For me, there's something fundamentally magical about the nature of cinema. I remember when I used to be a projectionist, and I would be all alone setting up the films on the projectors. There was that big white screen, and then people would come into the theater and sit down, and I'd bring the lights down-and all of a sudden this surprising new universe appeared on the screen that was completely immersive for an hour and a half or two hours. To me there's just magic in that. It's like closing your eyes and going to sleep, and suddenly you are conjuring up images from a place in your unconscious that may have a priori knowledge-you may be connected to a collective unconscious from ancient or primeval times that are beyond our ability to 
explain. So I just have an incredible love for that effort filmmakers make to put something meaningful on the screen. To share a dream experience. To share something profound that is perhaps beyond human reckoning.

\section{It's not easy coming back to LA}

CM: Let's go back to your career and the next film you made. Was it more difficult for you to get funding for Hunger? And what about its release and distribution? Seems like it was difficult. It was made in 2001 and released in 2007. Can you tell us about it?

MG: Hunger came out of a very difficult place. After When Saturday Comes I returned to Los Angeles and I was now single because after the shoot my ex-husband stayed behind with Sean Bean's wife, Melanie Hill. I had also graduated from UCLA film school so I didn't have the protective mechanisms of an institution behind me. I was represented by a top agent at William Morris Agency, but because When Saturday Comes did not get US distribution, it was as if I had never directed it.

And I had done a very female thing of deferring my directing pay on the film paripasu with all my multi-millionaire producers when I had no financial support system in place or income. So suddenly I was all alone in a rental apartment in LA, and I slipped very quickly into poverty. I realized things were going very wrong, but I didn't know what to do about it. I was coming up for directing jobs, and having great meetings, but in the end I was always passed over for a guy-and that meant no paychecks came in.

I was doing all this free development work for people, taking lousy screenplays and doctoring them, thinking I was attached as director, and then lo and behold, some guy would direct it. It was almost comical. I was constantly busy in development, coming up with all sorts of interesting ideas, with numerous pots on the fire, yet nothing paid off. Ultimately, I was having to cobble together an existence to be able to eat and pay rent. Still, I was always optimistic-sort of like Voltaire's Candide. I felt like I was walking through this utterly terrible landscape of horror that was Hollywood. I had all the best intent in the world, like some kind of cheerful, wellmeaning fool with bullets coming at me from every direction.

In the meantime, I was watching my male classmates and peers who I don't think were any more talented than me, and maybe even less hard-working than me, and they were making movie after movie, becoming the great masterful auteur directors of our time. I mean, I knew these guys and some of them were pretty mediocre, yet they were becoming acclaimed as the cinematic geniuses of our time.

\section{The making of Hunger}

My mother sent me a copy of Knut Hamsum's Hunger. I guess she thought it was her way of helping me navigate the difficult course my life had become. And it really did resonate with me. This existentialist masterpiece novel is about a writer wandering around Christiania (Norway) around 1890 trying to get work and literally starving to death. I was not literally starving to death, but spiritually I felt like I was. I remember I was in Barnes \& Noble bookstore one day going up an escalator and all of a sudden it just hit me suddenly that I should take this book and contemporize it for the screen. I 
should set it in Los Angeles and make it a starving screenwriter wandering around Los Angeles looking for a job. It was the perfect way for me to get back to work, while also exploring the experience I was going through.

So I spent the next few months writing the screenplay. I got it out to a few producers and agents, but nobody wanted to do it. Everybody thought it was too depressing. So I gave it to an actor friend of mine named Joseph Culp and he said, "Look, let's just do this." It was right at the time that all those brilliant Dogma films were coming out, making us all very optimistic about doing digital no-budget movies and changing cinematic history (laughs). So I said, "Why not, let's do it." We had no money, no equipment, nothing. We just decided we were going to do it for absolutely zero budget. A friend of mine lent me a Sony TRV900 camera, which is just like a bad 1990's home-video camera, it's not even broadcast quality. And I went ahead and committed my life to shooting this film starting in 1999.

We shot the movie in 25 days. And then things got really messy because I was working in the digital realm, and it was very cumbersome. My previous films had all been shot on $16 \mathrm{~mm}$ or $35 \mathrm{~mm}$ and cut on Steenbecks or upright Moviolas. Now we needed all these expensive, very heavy 9 Gigabyte drives. I remember driving all over the (San Fernando) Valley picking up five here, ten there-from people's garages. We had to practically fill a room with these goddamn 9 gigabyte drives that were also failing us and slowing things down.

My friend Sam Citron edited the film in this tiny little room we'd begged from a super high-end commercial production company called Cucolorus in Venice, CA. It was right across the street from Dudley Moore and Warren Beatty's famous restaurant, 72 Market Street. The industry was exploding, and with movie stars walking around in front of our office, and big productions getting made all around us, yet we were so far removed from it on some level. We were tucked away for months in this little closet where we were eventually forgotten. At a certain point I remember feeling like Bartleby the Scrivener. Eventually after many months the execs at Cucolorus noticed we were still there and told us to evacuate, but we didn't. We just kept staying until the movie was finally done.

\section{Hunger at the Nordkapp Film Festival}

Anyway, by 2001 I had completed the film, and it got really great reviews in several festivals. It was called "Pick of the pack" and "Shot on video wonder" and "the Champion"-you've seen those reviews. I began to harbor new hopes (laughs), but it didn't go any further than that. And all the major festivals ignored it. But finally it got noticed in Norway. The director, Knut Erik Jensen was making a documentary about Knut Hamsum for Norwegian TV and read about me and my film during online research. He brought a film crew all the way out to LA for a week and filmed me. It was a terrific boost to my self-esteem as a director, and he really loved the film. He was also head of the Nordkapp Film Festival in Honningsvag way, way up in the north of Norway-almost in the Arctic Circle, and he selected my film to open the festival. So, in this way, Hunger had its splendid world premiere in Norway in 2007. It got a passionate and protracted standing ovation which truly made all the years of effort 
worth it. And Knut Hansum's own grandson told me that he thought it was better than the 1966 version that won best actor award at Cannes Film Festival.

So, that Nordkapp experience gave me a lot of renewed confidence and hope. And I think in a certain sense it was kind of what set me off in my activism for women directors, too. Because I really decided at that point that I probably could have been a good filmmaker and that there was really a lot of sexism at play that had held me back in many ways. Then I started looking around and noticing that my female peers and classmates were nowhere to be seen either. I realized it wasn't just me, but all women that were losing out on opportunity. So I think the hidden success of Hunger triggered a certain rage inside of me that set me on this explosive last 8 years of activism for women directors. I just want to terrorize Hollywood on behalf of all women. I wanted to blow it up in a thousand ways-and in the end I did. I suppose that has been actually my greatest success.

DR: We'd like to talk some more about the movies before going back to activism. We wanted to ask you a question about the adaptation of the novel, which you explained, but we did have a question. You adapted it to LA, changed the art form, but you did keep the male character instead of a female character. Listening to you now, I was wondering if it was to maintain some distance with your situation which was clearly not positive, so did the decision not to change the gender, did it have something to do with that or was it just because you had the opportunity of working with this actor that you knew well? Why did you not change the gender basically?

\section{Female or male characters}

MG: Male or female, the character in my Hunger is me. I could have cast a man or a woman to play the role-it wasn't important. I didn't see that character as sexualized. It's a story about something else. But this brings up a very important point that can be seen from several perspectives: on the one hand, how we see ourselves in relationship to the female or male heroes in films is determined in large part not by sex, but by the treatment of that character. Most of the time, we identify with the hero (or anti-hero) because, whether male or female, the stories are designed that way, so the audience can step into those shoes and have the experience of transference.

Whatever our gender, we each have the capability of identifying with a character regardless of sex. And it's fun to step into the shoes of, say, Clint Eastwood or Idris Elba, or Bradley Cooper and see an adventure through their eyes. It's fun to step into Greta Garbo's or Gal Gadot's or Jennifer Lawrence's shoes, too. You don't have to share their sex to do that. On the other hand, of course, because nearly $100 \%$ of films over the past 125 years-and literally $100 \%$ in the 85 years between 1930 and 1985have been directed by men, most of our film stories are about men, and that has shaped humanity and how we see ourselves. And it makes us, even as female filmmakers sort of default to male characters. That's something that's most certainly changed for me in the past decade since I have woken up- almost all the films I'm trying to develop right now have female leads and are rooted in one way or another in female empowerment. Not that I wouldn't make a film all about men, it's just my eyes have been opened to the need for balance and my interest has shifted. 
I was not a strong feminist in the 1980s or 1990s-so many of us women who were children during the women's lib movement of the 1970's were complacent, or worse, were part of the backlash. We had to experience the downslope of opportunity in a deeply personal way to wake up. I was among those women-but I sure did wake up with a fury. I was so angry with myself and my generation for allowing the backslide, I was ready for martyrdom to catch us back up and restore the movement-restore progress for ourselves and the next generation. I think where women directors are concerned I came to the very forefront of it. It became a crusade for me I was willing to sacrifice everything for-but I'm jumping ahead.

\section{Career challenges and sex discrimination}

In my early years of struggle as a filmmaker, I never said I'm not experiencing success because I'm a woman, I told myself it was because I was not good enough. I think that's what most of us women were telling ourselves because we had no community and nothing to reflect off except for our male peers who, while facing enormous challenges in this incredibly competitive profession, had it significantly easier. We women were all sitting in our living rooms or wherever trying to compete in a world that didn't want us, that didn't care what we thought or said. And there was no community, no internet, no social media for us to change any of that. Later, it was my ability to harness that as an activist, that made it possible for me to create enormous change.

Male directors connected in all these different ways: in the Directors Guild, on sets, and socially. Hollywood was a world designed by men and controlled by men for men to succeed, and female director success was just an illusion.

\section{Casting male leads}

When I directed Hunger, I wasn't thinking of the gender identity of that character, I was thinking about what it feels like as an artist to be utterly shut out of the world of success. I identified with the hero (or anti-hero) in the novel, Hunger. Knut Hamsun had captured that universal experience of being prevented from pursuing greatness, of having to battle mediocrity when you know greatness is possible. I think about when Percival gets to meet the Fisher King. He could become a great knight himself, but he's missing something fundamental-he was not privy to the secrets of that special class. When he had the opportunity for inclusion into that superior realm, he didn't know what questions to ask. The mysteries were beyond him and he thought it was impolite to intrude-so he wasn't accepted in to the glorious life. I think that's sometimes how I feel as a woman living in this patriarchal world. And it makes me want to foment revolution to turn the whole thing upside-down.

\section{Igniting the feminist flame}

There's an element of frustration being female in this patriarchy after all these thousands of years. Because we are female, we feel we can never really come in fully, not really. And being shut out from ever being an "auteur director" in the $20^{\text {th }}$ or $21^{\text {st }}$ 
century is part of that sad continuum of being part of what amounts to a second class. Our world's storytelling, our cultural narrative, the voice of civilization, is simple not open to us... That's ultimately what I became obsessed with changing.

That's what ignited the fire inside of me to disrupt and explode Hollywood. The secret answer to the future of women rested in this one thing: we had to find a way to demand our equal participation in our storytelling. Because if we could do that, we could share in our cultural narrative, share in the economics of it, and in doing so become equal participants in the power structure of our civilization. After all these thousands of years, it could possibly come down to just one law to make all this happen. And of course that would become my mission. To make Title VII-Equal Employment Opportunity law in US entertainment media become the fulcrum for an immense social transformation.

DR: You kind of broached this topic already when you were explaining why you made When Saturday Comes, but we were wondering if there were any scenes you feel stand out that maybe a straight male director would not have done but that you chose to do or that came to you.

MG: I'm not sure. The question of the female gaze comes up all the time these days, and especially that I'm on a lot of panels and speaking in the public forum. Is there such a thing as a "female gaze"? It's a fascinating and complex question. I do deeply believe in the significance of the discussion, but I question our ability to define such a term universally when women have been so marginalized in our storytelling and employments as filmmakers. This applies not just to cinema in the past 130 years, but to all storytelling arts since the dawn of literature.

A term "female gaze" suggests also validating the term, "male gaze"- and then should we have all sorts of other "gazes"? Men have not been constricted by storytelling boxes into which they are supposed to fit, so why should women? It shouldn't be a mandate that women have to tell female stories. Men tell all sorts of stories across a vast spectrum of genres- a universal "male gaze" is not possible to define, in my view.

Women's voices and visions have been absented from our cultural narrative, and it is critically important to now include them fully- past, present and future, but we must be open to each voice on an individual basis and allow for full freedom of expression. Stamping female storytelling or filmmaking with definitions or standards or expectations is unfair, constraining, and demeaning to us as a sex, and I oppose it.

What I favor is strict adherence to equal employment opportunity laws in all our entertainment media industries, globally. And great unity and solidarity among all people who value the democratization of our storytelling in fully realizing that goal. Then, when we are on the road to equality, and especially when we have fully established it, let meritocracy (regardless of sex) determine success. And let our freely expressed voices and visions determine any possible sex-based definitions of "gaze."

\section{Children's cinema}




\section{CM: Do you have any projects?}

MG: I'm always working on lots of projects. I have a beautiful children's script that I have wanted to direct. It's set in Friesland in the Netherlands, and it's about a group of schoolchildren who go on a quest to find a wheel and so restore grace to their bereft little fishing community. And it's got a ten-year-old girl as its lead, and I'd love to make that film. I have a stockpile of other projects I'd like to make, and now that my profile is rising due to my work for gender equality in entertainment media, I'm getting quite a lot of submissions-scripts for me to direct. Some of them are very exciting projects.

My interest in children's cinema has grown since I had children quite late in life (I was 41 and 42 when I had my son and daughter who are now teenagers). Thanks to them, I became an enormous fan of Hayao Miyazaki. I would say Hayao Miyazaki (Studio Ghibli) is among the greatest feminist filmmakers of all time. His films nurtured my own feminism and have totally transformed, largely thanks to John Lasseter, children's animated cinema in the United States. Miyazaki's incredible love and celebration of women and girls and sisters, girlfriends, grandmothers and aunties has been truly transformative to the world. So I credit him a lot-

\section{Women directors in Hollywood in the 2010s}

DR: We wanted to ask you about the fact that, in the Academy Awards, for instance this year, some very brilliant women directors were forgotten, and there were lots of articles about it, but for instance Debra Granik who directed Leave No Trace, Lynne Ramsay You Were Never Really Here, one of the most beautiful movies I've seen in the past three years, Chloé Zhao The Rider, another one of the most beautiful movies I've seen in the last couple of years, and none of them were nominated. A couple of years back Ava DuVernay for Selma was not nominated either, which was kind of surprising. This is interesting because, as you said, it points to the fact that there's a systemic problem. And I've read studies that basically show that in independent cinema, in terms of gender, it's pretty close to 50/50 or $45 / 55$ or something, but in Hollywood, apart from Kathryn Bigelow, there aren't really any women directors who've been given the opportunity to have a career?

MG: Yes. I don't think there is an example of $50 \%$ women directors working anywhere in the world except perhaps Sweden, where the brilliant Anna Serner of the Swedish Film Institute was able to mandate 50/50 gender hiring. But let's talk about Hollywood. When I started going at this in 2012, about $13 \%$ of episodic TV shows were directed by women, and about $4 \%$ studio features were directed by women. And in commercials which is the most lucrative category of directing, women are almost completely absent-about $1 \%$. It's all about the money. Women are allowed in if you don't pay them, so for example about $39 \%$ of feature documentaries are directed by women in the US.

Today in 2019 things are changing-but only because of legal action, because of the ACLU and federal investigations. Hollywood needs the fear of lawsuits to hand jobs to women because stories are power. If $80 \%$ of entertainment media content that is distributed around the world comes out of Hollywood-that's a lot of influence.

Back in 2012, I started parsing out that 4\%-- who were the women directors that made up that $4 \%$ of studio feature film directors? And I started to see that almost $100 \%$ of that $4 \%$ were either movie stars, pop stars or the relatives of movie moguls. Angelina Jolie, Barbara Streisand, Madonna, Drew Barrymore, Jodie Foster, even Sofia 
Coppola and Kathryn Bigelow (daughters or wives of movie moguls, a billionaire). Each one of them was either rich or powerful enough to command executives, if not outright finance their own film by themselves. So, if you take them out, almost $0 \%$ of studio features are directed by just ordinary women, where does that leave girls, just anybody, and women of color, and little girls of color who might dream of doing this? Statistically, they don't have a chance. We should not be lying to our daughters, telling them they can become whatever they want. It's a lie. If we want to tell our daughters they can achieve their dreams, we'd damn well better change the world first so it's true.

It was this sort of thinking that gave me the impetus to battle for women directors in my union, to take it to the ACLU and the EEOC.

After battling my union, the Directors Guild of America, I went to the EEOC and ACLU. In 2014 the ACLU launched this massive media campaign putting women directors on the map, successfully got the EEOC to investigate in 2015-that investigation has now been going on for 4 years and six months-and thanks to that we are seeing a little bit of an upswing in terms of female director hires, particularly in television. In 2018 I think women directed $3.7 \%$ of studio features and I'm told that by $202012 \%$ to $14 \%$ of studio films will have been directed by women. Episodic TV shows directed by women will have jumped from $13 \%$ in 2013 to perhaps 30\% in 2020-that's a 130\% increase in six years. That's the power of legal action.

Okay, so to get back to your question: these beautiful films made last year by women directors were totally ignored in the Academy. Well, the fact of the matter is that it's a tiny hierarchy of power, of elite white liberal men in Hollywood, who occupy the high seats of power in all of the organizations in Hollywood.

You take a guy like Steven Spielberg, just as an example: he is not just a famous director who's made all these massively successful films, but he's also very powerful in every sector of the industry: unions, studios, networks, talent agencies, the Director's Guild of America, the Producers Guild of America, the Writers Guild of America, the Academy of Motion Pictures. He also owns a studio-Dreamworks-and he's a giant force at CAA. And he has powerful ties to Washington DC and the news media. These guys are running the whole show, controlling America's communications machinery, influencing geopolitics. They know how powerful they are, and they think they are making the world a better place. They think they have the right ethos to spread around the world-but guess what-they don't value women or female voices. They shut women out. They are fraught with bias. Before 2014 when the ACLU and EEOC pressure came, Spielberg hired just one female director (Mimi Leder) on the many, many feature films he produced. Turns out that is employment discrimination based on sex-it's not just wrong on a moral basis, it's also against the law. Check out his IMDB producer credits since 2014, he's hiring lots of women now (laughs).

We women get hit from every direction in a power structure like this. We make a movie, and we get a lower budget, shorter production schedules, worse distribution, low P\&A (print and advertising). And it's the same group of guys that are coming up and getting all the awards. I mean think about it. I'm a member of the Directors Guild of America, and so every year I get this big long list of hundreds and hundreds of films to pick from, and most of the names you don't recognize or you haven't even 
seen the films. Who has the time to see hundreds and hundreds of films every year? So people just gravitate to and select the names they know. And $80 \%$ of critics are men, they're inherently biased against female made films, giving men better reviews and better coverage.

So it's going to require revolution. We need to stop thinking about Hollywood as being a bunch of privately owned businesses in which the owners of the means of production have a right to bypass the law and do things their own way. We need to see Hollywood for what it is: the communication center for one of the most powerful nations in the world, the propaganda machine for the United States of America. And it is largely creating our cultural narrative for our entire world, which is helping to guide the trajectory of civilization.

You don't think that this little tiny group of superpower guys in Hollywood know this? It's like in the battle between the Koch brothers on one side and the oneworlders on the other; where is civilization going to go? It's largely going to be based on what stories we tell and what ethos people are convinced of. Hollywood leaders want to hang on to that incredible power of influence and of money.

I know I've made significant waves, but what power have we women got in the face of all of this? I was talking to this guy who had been a very big lobbyist in Washington DC, and he told me, "Those EEOC positions, they're all bought and paid for." So we managed to get this federal investigation going for women directors, and they got the EEOC to take on this investigation. But Hollywood pays hundreds of millions of dollars every year into the coffers of lobbyist groups in Washington DC to represent their interests in Hollywood. It is a very difficult battle to fight.

In the end, we can win by playing a strategic game in which we convince the world that this is not just a feminist issue, this is a civil rights issue-and it resonates nationally and globally.

Also, this is not a partisan issue, it's not a liberal or conservative issue. If women are shut out of contributing to our cultural narrative, our storytelling by being shut out of Hollywood as directors, so are conservatives.

\section{Beyond \#MeToo}

In 2017 right after the Weinstein scandal hit the news, I wrote a guest post for The Hollywood Reporter, and I really knew immediately that this shift over to \#MeToo from equal employment opportunity law was going to be problematic for the work I was doing. So I counted up all the films that Harvey Weinstein had executive produced and produced, and I found that he had only hired $2.7 \%$ women to direct the films he had executive produced or produced-2.7\%, less than 3.

Then I thought, so where does that put the great Hollywood icons that we all love and who have not sexually harassed and assaulted women-executive producers and producers like Steven Spielberg or George Clooney and Matt Damon. I counted up all the films that Steven Spielberg had produced and executive produced up to 2014 when the ACLU started in on this campaign, and as I mentioned before, he had hired only $1 \%$ women to direct the films that he executive produced. And George Clooney 
0\%. And Matt Damon 0\%. They were actually worse violators of employment discrimination than Weinstein was.

I started thinking, oh yes, Hollywood is happy burning Harvey Weinstein on this medieval sacrificial pyre to absolve all Hollywood of its collective sins against women, but really the real pain, where the real injury happens, is in not giving us the jobs. Sexual harassment and abuse in the workplace are just some of many symptoms resulting from employment discrimination. They are the result of power-imbalances founded in employment and pay inequality. It's all about money. And truly, given a choice, I would take sexual harassment any day over unemployment.

\section{Filmmaking, Film History and (Feminist) Film Theory}

CM: Our last question. Getting back to the narrative content of your films. We noted that obviously you make a lot of references to the history of cinema (Saturday Night and Sunday Morning, kitchen sink realism, Charlie Chaplin's little Tramp...), but would you say that film theory has also influenced the narrative, aesthetic, and political content of your films?

MG: I don't think a lot about film theory when I'm writing or directing, but ideas about how film functions, and images from films throughout film history are a part of me, so they are also part of my story-telling. This is I think why it's so important that $50 \%$ of our stories be told by women because we don't know what is going to come out of that. We don't know what visuals and what subtexts might come to be included in the great body of our global cinema that other people will take from. I have borrowed and made homages to many different things that I have seen from cinema in all of my years of life watching and studying film, but those come largely from a male body of work and a male perspective on the world. Can you explain a little bit more your question in terms of film theory?

CM: Sure! You went to film school in UCLA where obviously you gained a lot of background knowledge on film history and film theory. Do you feel you've been using it in your films? It's the case with a lot of film directors nowadays who self-consciously quote film theory and feminist film theory. For example, it is the case with some horror movies which integrate feminist scholarship into their narrative material, or with Todd Haynes who responds to feminist film scholars like Pam Cook and Laura Mulvey in Mildred Pierce. I was wondering if you had thought about doing this when you worked on When Saturday Comes.

MG: I try to avoid pretension in general in my work, so I try not to be overly conscious about theory. I know the influences really come from the films that have informed the stories I'm trying to tell. So as you say, for example, on When Saturday Comes I was very influenced by This Sporting Life, The Loneliness of the Long Distance Runner, and Saturday Night and Sunday Morning.

CM: So making references to film history and films rather than referring to film theory per se. What about Hunger, the reference to the Little Tramp is conscious, isn't it?

MG: Of course, I was using the character in Hamsun's Hunger to illustrate my own plight in Hollywood while referencing iconic figures from cinematic history, Charlie Chaplin on the one hand, and Lawrence of Arabia on the other. Each of them, like myself, is walking a tight-rope in life between sheer, hilarious mediocrity and potentially godlike greatness. The contradiction between what life is like, and what life could be like is so irreconcilable that in the end, what else can we do but laugh? We are just a step from oblivion and that's all the time we get. Show's over. So we do 
what we can. We try to tell stories to say, "I was here." We try to shape the world to be a better place for the next gang coming in.

Anyway, that is what directors do: we have a vision, and in attempting to realize that vision we find a thousand problems we need to solve along the way. On my journey I found that women are not fully allowed to direct films, so I had to solve that problem for all of us along the way. And ultimately, that's the message of my film Hunger- at first Charlie Pontus gets defeated by Hollywood, he has to hitch a ride on a big rig truck out of LA-he's exiled. But in the end he writes the book. And it's a masterpiece, right? He triumphs over this industry that is like an existential vortex. That's his redemption. Well, I do think that Hunger is my favorite piece of work I've ever made ... and yet no one has seen it.

CM: Well, we have!

INDEX

Mots-clés: Maria Giese, réalisatrices, féminisme, militantisme, Hollywood, discrimination, Jimmy, Hunger

Keywords: Maria Giese, women directors, feminism, activism, Hollywood, discrimination, When Saturday Comes, Hunger

Subjects: Film, TV, Video

\section{AUTHORS}

\section{CRISTELLE MAURY}

Maîtresse de conférence

Université Toulouse Jean Jaurès

cristellemaury@gmail.com

\section{DAVID ROCHE}

Professeur

Université Paul Valéry Montpellier 3

mudrockca@gmail.com 